\title{
Neurological symptoms after parenteral nutrition
}

\author{
Alexander Vogel, ${ }^{1}$ Thibault Humbert, ${ }^{1}$ Ioannis Rotas, ${ }^{1}$ Céline Forster ${ }^{1,2}$
}

${ }^{1}$ Visceral Surgery, Sion Hospital Valais Romand Hospital Center, Sion, Valais, Switzerland ${ }^{2}$ Thoracic Surgery, Sion Hospital Valais Romand Hospital Center, Sion, Valais, Switzerland

Correspondence to Dr Céline Forster: celine.forster@hopitalvs.ch

$\mathrm{AV}$ and $\mathrm{TH}$ contributed equally.

$\mathrm{AV}$ and $\mathrm{TH}$ are joint first authors.

Accepted 5 August 2021

Check for updates

(c) BMJ Publishing Group Limited 2021. No commercial re-use. See rights and permissions. Published by BMJ.

To cite: Vogel A, Humbert T, Rotas I, et al. BMJ Case Rep 2021;14:e245182. doi:10.1136/bcr-2021245182

\section{DESCRIPTION}

A 67-year-old woman consulted the emergency department because of a 3-day story of abdominal pain and vomiting. Since 12 years she was following a multimodal management of a rectal cancer with no recurrence since. An abdominal CT scan was performed and demonstrated a mechanical ileus with proximal jejunal dilation $(47 \mathrm{~mm})$ without free peritoneal air or fluid. She was taken to the operation room for a laparotomy with extended adhesiolysis and peritoneal washing. At the end of the surgery, a central catheter was placed in the right jugular vein under ultrasound guidance for parenteral nutrition (Omegaflex) to cover the period of oral fasting during her abdominal recovery. On the eighth day after surgery, the central line became dysfunctional and was switched on a guide wire. The patient was recovering well from abdominal surgery but developed a sudden transient paraesthesia of her right lower limb concomitant to the reinitiation of her parenteral nutrition. A CT scan of the brain followed by an MRI showed multiple ischaemic lesions in the right anterior cerebral artery and the right posterior inferior cerebellar artery territories (shown in figure 1). The differential diagnosis for this observation was likely vascular. The patient had no history of atrial fibrillation or carotid atherosclerosis. The CT scan also showed that the central venous had transected the jugular vein and travelled through the subclavian artery to the aortic cross (shown in figure 2). All treatments administered by the central venous line were stopped and the central line was removed surgically
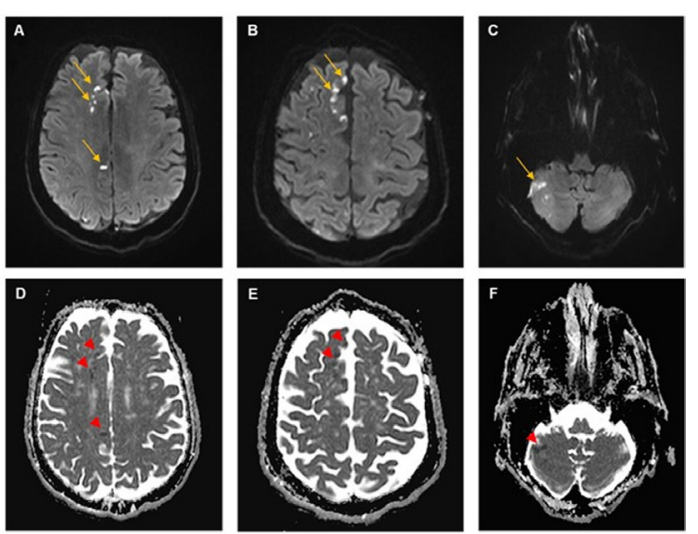

Figure 1 Axial diffusion-weighted magnetic resonance imaging (DWI-MRI) images (A-C) showing high signal intensity ischaemic lesions (arrows) in the right anterior cerebral artery territory $(A, B)$ and the right posterior inferior cerebellar artery territory (C). Corresponding apparent diffusion coefficient (ADC) maps (D-F) showing low signal intensity (arrowheads) indicating the acute nature of the lesions.

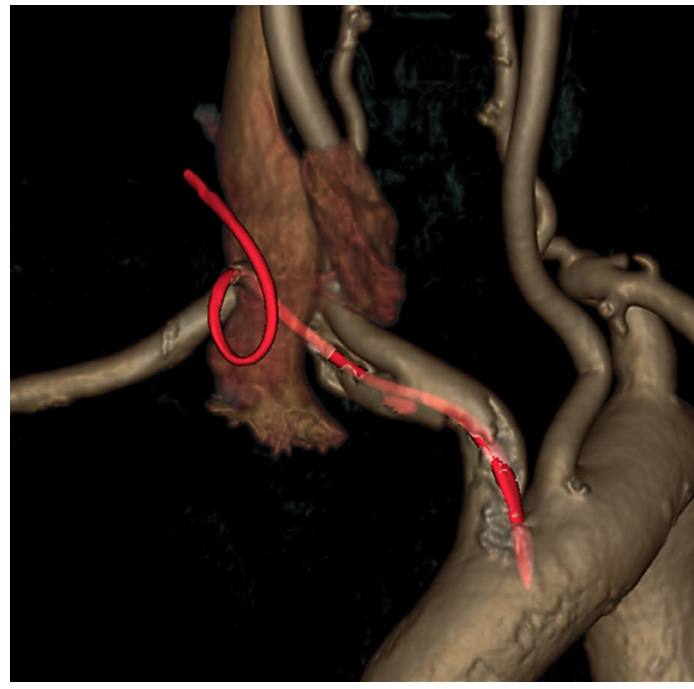

Figure 2 Three-dimensional volume rendition showing the trajectory of the central venous catheter, transecting the right jugular vein and travelling through the subclavian artery to the aortic cross.

\section{Patient's perspective}

I have now totally recovered and I am happy with this publication, since it can help further doctors to recognise this complication of central venous catheter malposition.

\section{Learning points}

- Complications of central venous catheter misplacement might be severe and must be recognised quickly.

- Lipids of parenteral nutrition administered intraarterially can cause ischaemic cerebral lesions.

by cervicotomy. ${ }^{1-3} \mathrm{~A}$ second reading of the brain MRI confirmed the ischaemic lesions were related to the lipids of the parenteral nutrition administered intra-arterially. The patient was discharged 12 days after initial abdominal surgery.

Contributors All authors contributed to the planning and writing of the article and reviewed the article.

Funding The authors have not declared a specific grant for this research from any funding agency in the public, commercial or not-for-profit sectors.

Competing interests None declared.

Patient consent for publication Obtained. 
Images in...

Provenance and peer review Not commissioned; externally peer reviewed.

2 Gibson F, Bodenham A. Misplaced central venous catheters: applied anatomy and practical management. Br J Anaesth 2013;110:333-46.

\section{REFERENCES}

3 Lennon M, Zaw NN, Pöpping DM, et al. Procedural complications of central venous catheter insertion. Minerva Anestesiol 2012:78:1234-40.

Stone PA, Hass SM, Knackstedt KS, et al. Malposition of a central venous catheter into the right internal mammary vein: review of complications of catheter misplacement.

Vasc Endovascular Surg 2012;46:187-9.

Copyright 2021 BMJ Publishing Group. All rights reserved. For permission to reuse any of this content visit https://www.bmj.com/company/products-services/rights-and-licensing/permissions/

BMJ Case Report Fellows may re-use this article for personal use and teaching without any further permission.

Become a Fellow of BMJ Case Reports today and you can:

- Submit as many cases as you like

- Enjoy fast sympathetic peer review and rapid publication of accepted articles

Access all the published articles

Re-use any of the published material for personal use and teaching without further permission

\section{Customer Service}

If you have any further queries about your subscription, please contact our customer services team on +44 (0) 2071111105 or via email at support@bmj.com.

Visit casereports.bmj.com for more articles like this and to become a Fellow 